\title{
The Phanerozoic Record of Global Sea-Level Change
}

\author{
Kenneth G. Miller, ${ }^{1 *}$ Michelle A. Kominz, ${ }^{2}$ James V. Browning, ${ }^{1}$ James D. Wright, ${ }^{1}$ Gregory S. Mountain, ${ }^{1,3}$ Miriam E. Katz, ${ }^{1}$ \\ Peter J. Sugarman, ${ }^{4}$ Benjamin S. Cramer, ${ }^{1,5}$ Nicholas Christie-Blick, ${ }^{3}$ Stephen F. Pekar ${ }^{3,6}$
}

\begin{abstract}
We review Phanerozoic sea-level changes [543 million years ago $(\mathrm{Ma})$ to the present] on various time scales and present a new sea-level record for the past 100 million years (My). Long-term sea level peaked at $100 \pm 50$ meters during the Cretaceous, implying that ocean-crust production rates were much lower than previously inferred. Sea level mirrors oxygen isotope variations, reflecting ice-volume change on the $10^{4}$ - to $10^{6}$-year scale, but a link between oxygen isotope and sea level on the $10^{7}$-year scale must be due to temperature changes that we attribute to tectonically controlled carbon dioxide variations. Sea-level change has influenced phytoplankton evolution, ocean chemistry, and the loci of carbonate, organic carbon, and siliciclastic sediment burial. Over the past $100 \mathrm{My}$, sea-level changes reflect global climate evolution from a time of ephemeral Antarctic ice sheets (100 to $33 \mathrm{Ma}$ ), through a time of large ice sheets primarily in Antarctica (33 to $2.5 \mathrm{Ma}$ ), to a world with large Antarctic and large, variable Northern Hemisphere ice sheets (2.5 Ma to the present).
\end{abstract}

$\mathbf{F}$ luctuations in global sea level (eustasy) result from changes in the volume of water in the ocean or the volume of ocean basins (Fig. 1) (1-4). Water-volume changes are dominated by growth and decay of continental ice sheets, producing highamplitude, rapid eustatic changes [up to 200 $\mathrm{m}$ and $20 \mathrm{~m}$ per thousand years (ky)]. Other processes that affect water volume occur at high rates $(10 \mathrm{~m} / \mathrm{ky})$ and low amplitudes $(\sim 5$ to $10 \mathrm{~m})$ : desiccation and inundation of marginal seas, thermal expansion and contraction of seawater, and variations in groundwater and lake storage. Changes in ocean basin volume are dominated by slow variations in sea-floor spreading rates or ocean ridge lengths (100 to $300 \mathrm{~m}$ amplitude, rates of $10 \mathrm{~m} / \mathrm{My}$ ). Variations in sedimentation cause moderate amplitude $(60 \mathrm{~m})$, slow changes (10 m/My). Emplacement of oceanic plateaus produces moderately rapid rises $(60 \mathrm{~m} / \mathrm{My})$ but slow falls due to thermal subsidence $(10 \mathrm{~m} / \mathrm{My})$.

Eustatic variations can be estimated from satellite measurements, tide gauges, shoreline markers, reefs and atolls, oxygen isotopes

${ }^{1}$ Department of Geological Sciences, Rutgers University, Piscataway, NJ 08854, USA. ${ }^{2}$ Department of Geosciences, Western Michigan University, Kalamazoo, MI 49008-5150, USA. ${ }^{3}$ Lamont-Doherty Earth Observatory of Columbia University, Palisades, NY 10964, USA. ${ }^{4}$ New Jersey Geological Survey, Post Office Box 427, Trenton, NJ 08625, USA. ${ }^{5}$ Department of Geological Sciences, University of Oregon, Eugene, OR 974031272, USA. ${ }^{6}$ School of Earth and Environmental Sciences, Queens College, 65-30 Kissena Boulevard, Flushing, NY 11367, USA.

*To whom correspondence should be addressed: kgm@rci.rutgers.edu $\left(\delta^{18} \mathrm{O}\right)$, and the flooding history of continental margins and cratons. Satellite measurements are limited to the past 10 years (5), whereas tide gauge records extend back only $\sim 150$ years (3). The most recent pre-anthropogenic sea-level rise began at about $18 \mathrm{ka}$ and can be measured by directly dating shoreline markers (fig. S1). Tropical reefs and atolls (fig. S2) provide the most reliable geological estimates by dating "fossil sunshine" (e.g., shallowdwelling corals) and have provided a precise estimate for the last sea-level lowstand $(120 \pm$ $5 \mathrm{~m}$ below present at $18 \mathrm{ka}$ ) (fig. S2) $(6,7)$. However, most coral records are from regions with complicated uplift/subsidence histories, are difficult to recover and date (particularly beyond a few $100 \mathrm{ky}$ ), and have poorly preserved lowstand deposits.

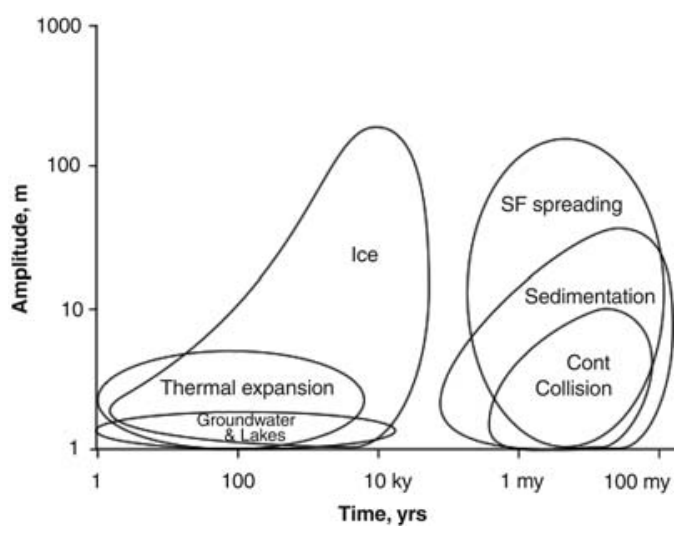

Fig. 1. Timing and amplitudes of geologic mechanisms of eustatic change derived from (1-4). SF, sea floor; Cont, continental.
The growth and decay of continental ice sheets causes eustatic changes that are indirectly recorded in the chemistry of foraminifera because ice has lower $\delta^{18} \mathrm{O}$ values than seawater (fig. S2) [e.g., $(8,9)]$. Oxygen isotope values provide a proxy for glacioeustasy, but $\delta^{18} \mathrm{O}$-based reconstructions are subject to several uncertainties: (i) Calcite $\delta^{18} \mathrm{O}$ values also vary as a function of temperature. (ii) Surface-ocean $\delta^{18} \mathrm{O}$ values are influenced by local evaporation-precipitation effects on seawater. (iii) Postdepositional alteration (diagenesis) may overprint original $\delta^{18} \mathrm{O}$ values, limiting useful records to sediments younger than 100 My.

Continents have been flooded many times in the geologic past (Fig. 2). However, the flooding record is not a direct measure of eustatic change because variations in subsidence and sediment supply also influence shoreline location. Regional unconformities (surfaces of erosion and nondeposition) divide the stratigraphic record into sequences and provide a key to eustatic change. Unconformities result from sea-level fall or tectonic uplift (10-12). Similar ages of sequence boundaries on different continents have been interpreted as indicating that the surfaces were caused by a global process, eustasy [e.g. $(10,11)]$. The linkage with $\delta^{18} \mathrm{O}$ increases for the past $40 \mathrm{My}$ (13) indicates that most sequence boundaries resulted from eustatic falls driven by the growth of continental ice sheets.

Although unconformities potentially provide the timing of eustatic lowstands, extracting global sealevel history from the stratigraphic record requires a quantitative method that distinguishes the contributions of eustasy, subsidence, and sediment accumulation. Backstripping is an inverse technique that can be used to quantitatively extract sealevel change amplitudes from the stratigraphic record. It accounts for the effects of sediment compaction, loading (the response of crust to overlying sediment mass), and water-depth variations on basin subsidence (14). Tectonic subsidence at a passive margin is modeled with thermal decay curves and removed 


\section{R E V I E W}

to obtain a quantified eustatic estimate in the absence of local tectonic complexities.

We review the record of and uncertainties in eustatic changes over the past 543 My on three time scales: (i) a long-term trend $\left(10^{7}\right.$ to $10^{8}$ years) that has been attributed largely to variations in sea-floor spreading; (ii) the $10^{6}$ year scale that is among the most prominent features of the stratigraphic record; and (iii) the $10^{4}$ - to $10^{5}$-year scale that is dominated by changes in ice volume and controlled by astronomical variations in insolation. We present a new eustatic record for the past $100 \mathrm{My}$, with implications for causal mechanisms for both $10^{7}$ - and $10^{6}$-year changes.

\section{Long-Term Flooding of Continents}

Sloss (15) recognized that North America experienced five major Phanerozoic floodings (Fig. 2) and attributed these changes to subsidence and uplift of the craton. Vail and colleagues at Exxon Production Research Company (EPR) recognized similar $10^{7}$ - to $10^{8}$-year scale "supersequences" that they attributed to global sea-level changes $(10,11,16)$. Others have reconstructed continental flooding history on the $10^{7}$ - to $10^{8}$-year scale $(4,17-19)$ (Fig. 2) and inferred eustatic changes from commonalities among continents.
High Late Cretaceous sea level has been attributed to high ocean-crust production rates that resulted in more buoyant ridges displacing seawater onto low-lying parts of continents ("tectonoeustasy") (20). This concept has been extended to the Paleozoic through Early Mesozoic by assuming that $10^{7}$ - to $10^{8}$-year scale continental flooding was caused by high seafloor spreading rates, even though direct evidence for sea-floor spreading rates is absent owing to subduction.

Our sea-level record for the past $100 \mathrm{My}$ has much lower amplitudes on the $10^{7}$ - to $10^{8}$-year scale than previously inferred (Figs. 2 and 3 and fig. S3), with implications for sealevel change from 543 to $100 \mathrm{Ma}$. Our 100 to $7 \mathrm{Ma}$ record (Fig. 2) is based on backstripping stratigraphic data from five New Jersey coastal plain coreholes $(21,22)$. Similar estimates obtained for each site suggest that we successfully accounted for the effects of thermal subsidence, sediment loading, compaction, and water-depth variations. Our long-term trend indicates that sea level was 50 to $70 \mathrm{~m}$ above present in the Late Cretaceous $(\sim 80 \mathrm{Ma})$, rose to 70 to $100 \mathrm{~m}$ from 60 to $50 \mathrm{Ma}$, and fell by $\sim 70$ to $100 \mathrm{~m}$ since $50 \mathrm{Ma}$ (23). This contrasts with previously reported Late Cretaceous sea-level peaks of about 250 to $320 \mathrm{~m}$ based on sea-floor spreading reconstructions (2), although it is within error estimates of 45 to $365 \mathrm{~m}$ (best estimate $230 \mathrm{~m}$ ) (24). It is lower than global continental flooding estimates $[150 \mathrm{~m}$ (19), 80 to $200 \mathrm{~m}$ (18)].

Our results are similar to backstripped estimates from the Scotian and New Jersey continental shelves (14), although the Late Cretaceous peak is lower (50 to $70 \mathrm{~m}$ versus $\sim 110 \mathrm{~m}$ ) (fig. S3). One-dimensional (1D) backstripping may underestimate the Late Cretaceous peak because coastal plain subsidence results from a thermoflexural effect (14), and thermal subsidence curves may slightly overestimate the tectonic portion of subsidence of the older section. Considering backstripping and continental flooding estimates $(18,19)$ and errors in our paleowater depth estimates (eustatic error of \pm 10 to $35 \mathrm{~m}$ ), we conclude that sea level in the Late Cretaceous was $100 \pm 50 \mathrm{~m}$ higher than it is today.

Using new sea-floor age data, Rowley (25) suggested that there have been no changes in sea-floor spreading rates over the past $180 \mathrm{My}$. Our record implies a modest decrease in the rate of ocean-crust production because the longterm eustatic fall of 70 to $100 \mathrm{~m}$ since the early Eocene (Fig. 3) cannot be totally ascribed to permanent growth of ice sheets (26).

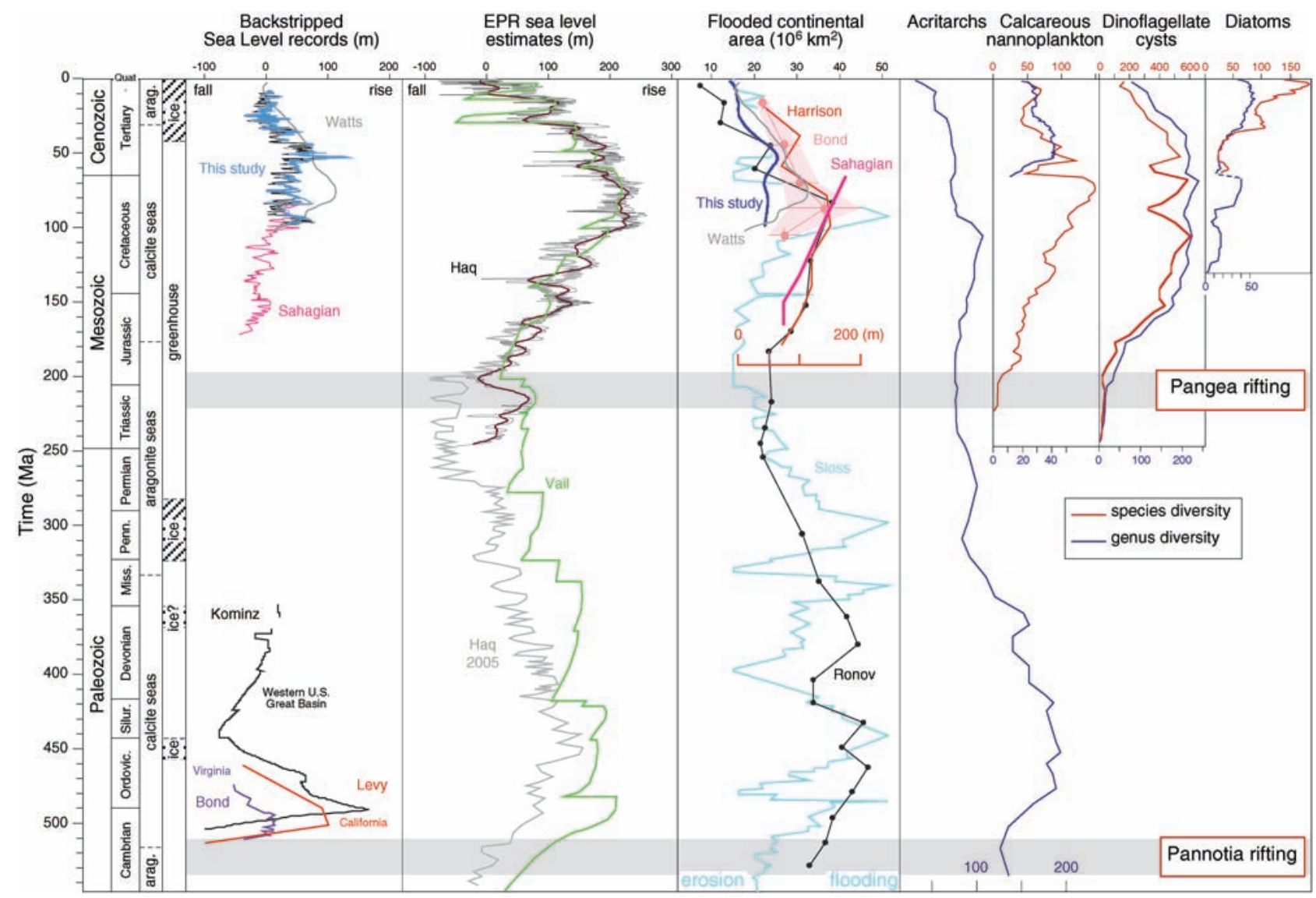

Fig. 2. Comparison of Phanerozoic backstripped eustatic estimates of this study, Watts (14), Sahagian (35), Kominz (29), Levy (30), and Bond (18); EPR records of Vail $(10)$ and Haq $(11,16)$; continental flooding records of
Sloss (15) and Ronov (17) plotted versus area, and Bond (18), Harrison (19), and Sahagian (4) plotted versus sea level; and evolutionary records compiled by Katz (52). 
Our observation that long-term eustatic changes were appreciably smaller than previously thought has implications for geochemical models [e.g., (27)] that have used sea-level records to scale ocean production rates. Estimates derived from backstripping from the past 170 My (Fig. 2) show much lower long-term amplitudes than those published by EPR. Backstripped sea-level records from the Cambrian-Devonian of the western United States show 200-m amplitudes on the $10^{7}$-year scale $(28-30)$ (Fig. 2), although a CambrianOrdovician backstripped data set from the Appalachians shows a lower ( $\sim 70 \mathrm{~m}$ ) amplitude (Fig. 2) (28). The sea-level rise in the Cambrian is attributed to the generation of new ocean ridges with the breakup of Pannotia (29), but the amplitude of this rise is still uncertain. Although the jury is still out on the amplitudes of Paleozoic sea level on the $10^{7}$-year scale, our work suggests that the EPR records cannot be used to scale past spreading rates.

Sea-level changes on very long time scales (250 My) are related to the assembly and breakup of supercontinents. Formation of the supercontinents Pannotia (late Proterozoic to Early Cambrian) and Pangea (Permian to early Triassic) was associated with low levels of continental flooding (Fig. 2). This may be attributed to (i) a eustatic effect due to thickening of continents during orogeny resulting in increased oceanic area (2) and/or (ii) higher elevations that result when trapped heat builds up below the supercontinents (31).

\section{Million-Year Scale Changes}

In 1977, EPR surprised academic and industrial colleagues with the publication of a Phanerozoic eustatic record that showed more than 50 falls, some as large as $400 \mathrm{~m}$ (10). In 1987, the EPR group published a series of papers, including a synthesis in Science (11) that reported more than 100 sea-level falls during the past $250 \mathrm{My}$, with a maximum fall of $160 \mathrm{~m}$. The EPR studies came under intense scrutiny because of the novel sugges-

tions that (i) sequence boundaries are timeimportant features that could be recognized on seismic profiles and (ii) seismic profiles could be used to determine the history of sea level. The EPR curves have been strongly criticized for their methodology $(12,32)$, with critics sug- gesting that coastal onlap curves presented cannot be translated into a eustatic estimate.

Drilling on the New Jersey margin has provided new insights into the amplitudes of and mechanisms for $10^{6}$-year scale sea-level changes. Fourteen Late Cretaceous sequences

the Cenozoic (13) and \pm 1.0 My for the Late Cretaceous (33). Onshore New Jersey sequence boundaries correlate with sequence boundaries in the Bahamas, northwest Europe, the U.S. Gulf Coast, Russia, offshore New Jersey, and those of EPR, which suggests that they are global and formed in response to eustatic falls $(13,33)$. Thus, drilling has validated the number and timing, although not the amplitude, of many of the EPR sea-level events for the past $100 \mathrm{My}(13,33)$. OligoceneMiocene sequence boundaries can be firmly linked with global $\delta^{18} \mathrm{O}$ increases, demonstrating a causal relation between sea level and ice volume $(13,33)$, as expected for the Icehouse world of the past 33 My.

Backstripping of the New Jersey records provides eustatic estimates from $\sim 100$ to $7 \mathrm{Ma}$ (Fig. 3). Paleocene-Eocene and Miocene estimates are derived from 1D backstripped records from five sites and Late Cretaceous sequences from two sites (34). Several Upper Cretaceous onshore sections capture full amplitudes of change; however, many Cretaceous and most Cenozoic onshore sections do not record sea-level lowstands. Eustatic estimates for the latest Eocene to earliest Miocene are derived from 2D backstripping (22) that addressed this problem.

Our backstripped eustatic estimate (table S1) shows that global sea level changed by 20 to $80 \mathrm{~m}$ during the Late Cretaceous to Miocene (this study) and the Middle Jurassic to Late Cretaceous (35). Our comparison shows that the amplitudes of the EPR sea-level curve, including the most recent update (16), are at least 2.5 times too high (Fig. 2 and fig. S3).

Eustatic changes with amplitudes of $10 \mathrm{~s}$ of meters in less than 1 My pose an enigma for a supposedly ice-free Greenhouse world, because ice-volume changes are the only known means of producing such large and rapid changes. Our record (Fig. 3) quantifies high ampli-

and 33 Paleocene-Miocene sequences were identified in New Jersey coastal plain coreholes $(13,33)$ and dated by integrating biostratigraphy, Sr-isotopic stratigraphy, and magnetostratigraphy to produce a chronology with age resolution of better than $\pm 0.5 \mathrm{My}$ for tudes and rates of eustatic change $(>25 \mathrm{~m}$ in $<1 \mathrm{My})$ in the Late Cretaceous to Eocene Greenhouse world. Based on the sea-level history, we have proposed that ice sheets existed for geologically short intervals (i.e., lasting $\sim 100 \mathrm{ky}$ ) in the previously assumed 
ice-free Late Cretaceous-Eocene Greenhouse world (36). This view can be reconciled with previous assumptions of an ice-free world. Sea-level changes on the $10^{6}$-year scale were typically $\sim 15$ to $30 \mathrm{~m}$ in the Late CretaceousEocene ( $\sim 100$ to $33.8 \mathrm{Ma}$ ), suggesting growth and decay of small- to medium-sized (10 to $\left.15 \times 10^{6} \mathrm{~km}^{3}\right)$ ephemeral Antarctic ice sheets (36). These ice sheets did not reach the Antarctic coast; as a result, coastal Antarctica and deep-water source regions were warm even though there were major changes in sea level as the result of glaciation (36). These ice sheets existed only during "cold snaps," leaving Antarctica ice-free during much of the Greenhouse Late Cretaceous to Eocene (36).

Sea-level changes on the $10^{6}$-year scale occurred throughout the Phanerozoic. Studies from the Russian platform and Siberia provide backstripped records of $10^{6}$-year sea-level changes that are remarkably similar to New Jersey in the interval of overlap and extend to the Middle Jurassic ( $\sim 170 \mathrm{Ma})$ (35). The stratigraphic record before $170 \mathrm{Ma}$ is replete in $10^{6}$-year sea-level changes $(16,37)$. However, it is unclear whether these variations represent global changes in sea level. Eustatic estimates have been extracted from backstripping of Paleozoic strata $(28,29)$ (Fig. 2), although differences in the Appalachian versus the western U.S. Cambrian-Ordovician sea-level amplitude estimates are large, and thus the eustatic imprint is ambiguous.

Eustatic changes on the $10^{4}$ - to $10^{6}$-year scales were controlled primarily by variations in ice volume during the past $100 \mathrm{My}$ and may be expected to be modulated by both short-period [19/23 (precession), 41 (tilt), and $\sim 100$ ky (precession)] and long-period [1.2 (tilt) and 2.4 My (precession)] astronomical variations (38). Spectral analysis of our sealevel records shows that variations occur with an as-yet-unexplained, persistent 3-My beat and a second primary period varying from 6 to $10 \mathrm{My}$ (fig. S4). Amplitudes in the $~ 3-\mathrm{My}$ bandwith are $\sim 10 \mathrm{~m}$ from 60 to $20 \mathrm{Ma}$, with lower amplitude from 90 to $60 \mathrm{Ma}$.

The existence of continental ice sheets in the Greenhouse world is a controversial interpretation, but the study of ice-volume history has progressively tracked ice sheets back through the Cenozoic (36). After extensive debate, a consensus has developed that ice volume increased markedly in the earliest Oligocene $(8,9)$. We suggest that, at that time, the Antarctic ice sheet began to be a forcing agent of, and not just a response to, ocean circulation (36). The Antarctic continent (including west Antarctica) (39) was entirely covered by ice, and sea level was lower by $\sim 55 \mathrm{~m}(22)$. As a result, latitudinal thermal gradients (40) and deep-water circulation rates increased [with pulses of Southern Component and Northern Component Water (41)]. Diatoms diversified rapidly in response to increased surface-water circulation and nutrient availability (Fig. 2), resulting in increased export production and a positive feedback on $\mathrm{CO}_{2}$ drawdown and cooling.

The earliest Oligocene event represented a major change in climate state from a Greenhouse world with cold snaps to the Icehouse world that continues today. Sea-level changes from the Oligocene to the early Pliocene ( $\sim 33.8$ to 2.5 Ma) were $\sim 30$ to $60 \mathrm{~m}$ (Figs. 3 and 4), with growth and decay of a large (up to present volumes of $25 \times 10^{6} \mathrm{~km}^{3}$ ) ice sheet mostly in Antarctica. A middle Miocene $\delta^{18} \mathrm{O}$ increase is associated with deep-water cooling and two ice-growth events that resulted in the permanent development of the East Antarctic ice sheet (40). Northern hemisphere ice sheets (NHIS) have existed since at least the middle Miocene (41), but large NHIS with sea-level changes of 60 to $120 \mathrm{~m}$ only began during the late Pliocene to Holocene ( 2.5 to $0 \mathrm{Ma})$ (Fig. 4).

\section{Milankovitch Scale Changes}

The growth and decay of NHIS (the late Pliocene-Holocene "ice ages") and attendant sea-level changes were paced by $10^{4}$ - to $10^{5}$ year scale Milankovitch changes. The $\delta^{18} \mathrm{O}$ record shows a dominant 100 ky (eccentricity) beat over the past $800 \mathrm{ky}$, with secondary 19/23 (precession) and 41-ky (tilt) periods (42). Before $\sim 800 \mathrm{ky}$, the tilt cycle dominated $\delta^{18} \mathrm{O}$ (43) and sea-level records. Although strong precessional and eccentricity beats occur in the carbon system, the tilt cycle has dominated $\delta^{18} \mathrm{O}$ and ice-volume records for much of the past 33.8 My (9). Growth and decay of smallto medium-sized ice sheets in the Late Cretaceous-Eocene on the Milankovitch scale probably lie near or below the detection limit of $\delta^{18} \mathrm{O}$ records $[\sim 0.1$ per mil $(\%)=10-\mathrm{m}$ eustatic change].

Continental margins record $10^{4}$ - to $10^{5}$-year scale sea-level changes only in very high sedimentation rate settings. Foraminiferal $\delta^{18} \mathrm{O}$ records reflect ice volume in addition to temperature changes and potentially provide a proxy for sea-level changes on the $10^{4}$ - to $10^{5}$-year scale. The $\delta^{18} \mathrm{O}$ record provides continuity and excellent age control, although assumptions about thermal history must be made to use it as a sea-level proxy. In addition, diagenesis complicates planktonic foraminiferal $\delta^{18} \mathrm{O}$ records, although benthic foraminifera generally show little evidence for diagenesis at burial depths less than 400 to $500 \mathrm{~m}$ (44).

We derive sea-level estimates from 9 to 0 Ma using benthic foraminiferal $\delta^{18} \mathrm{O}$ records because the New Jersey record is incomplete from 7 to $0 \mathrm{Ma}$ (table $\mathrm{S} 1$ ). We scaled the benthic foraminiferal $\delta^{18} \mathrm{O}$ record (45) to sea level by making minimum assumptions about ocean thermal history (Fig. 4). The resultant sea-level curve (Fig. 4) aligns remarkably well with the backstripped record from 9 to $7 \mathrm{Ma}$ (Fig. 3).

Our $\delta^{18} \mathrm{O}$-derived sea-level estimate for the past 9 My (Fig. 4) shows that the record is dominated by the response to the 41-ky period tilt forcing, which increases in amplitude toward the present, and a low-amplitude 21-ky precession response. The major 100-ky events of the past $900 \mathrm{ky}$ stand out in the sea-level record (Fig. 4). There are prominent $10^{6}$-year scale sea-level falls (the 2.5, 3.3, 4.0, 4.9, 5.7, and 8.2 Ma events) (Fig. 4), but these are not obviously paced by amplitude modulations of either precession or tilt (fig. S4).

\section{Suborbital Scale}

Very large ( $>100 \mathrm{~m})$ sea-level rises are associated with glacial terminations of the past $800 \mathrm{ky}$ (fig. S1) (6). The most recent rise that followed the last glacial maximum at $18 \mathrm{ka}$ occurred as two major steps associated with meltwater pulses (MWP) 1a (13.8 ka) and 1b (11.3 ka), punctuated by a slowing at $\sim 12 \mathrm{ka}(6)$. Sealevel rise slowed at about 7 to $6 \mathrm{ka}$ (fig. S1). Some regions experienced a mid-Holocene sealevel high at $5 \mathrm{ka}$, but we show that global sea level has risen at $\sim 1 \mathrm{~mm} /$ year over the past 5 to $6 \mathrm{ky}$. We present new core data from New Jersey covering the past 6 ky that show a rise of $2 \mathrm{~mm} /$ year over the past $5 \mathrm{ky}$ (fig. S1). This New Jersey curve is remarkably similar to sea-level records from Delaware (46) and southern New England (47), with a eustatic rise of $1 \mathrm{~mm} /$ year over the past $5 \mathrm{ky}$ once corrected for subsidence effects (48), virtually identical to that obtained from Caribbean reef localities (49) (fig. S1) accounting for subsidence.

\section{Error Estimates}

Long-term sea-level estimates show considerable differences, with a large range of Late Cretaceous sea-level estimates: $\sim 110 \mathrm{~m}$ (14), $150 \mathrm{~m}$ (19), $250 \mathrm{~m}$ (4), and 80 to $200 \mathrm{~m} \mathrm{(18),}$ and our best estimate of $100 \pm 50 \mathrm{~m}$. We conclude that sea-level amplitudes on this scale were substantially lower than generally believed (100 versus $250 \mathrm{~m}$ ) over the past $170 \mathrm{My}$, with uncertain amplitude before this (Fig. 2).

Sea-level estimates on the $10^{6}$-year scale have an uncertainty, typically, of at best \pm 10 to $\pm 50 \mathrm{~m}$. The two main sources of errors in backstripping relate to hiatuses (time gaps) and paleowater depth estimates. New Jersey coastal plain sequences represent primarily inner-shelf to middle-shelf environments, with eustatic errors from paleowater depth estimates of \pm 10 to $20 \mathrm{~m} \mathrm{(50)}$. Hiatuses in our record potentially explain why amplitudes of change might not be fully recorded, and the effect of hiatuses can be evaluated only by comparing our record with other regions. Drilling on the Marion Plateau (offshore northeast Australia) targeted an $\sim 11 \mathrm{Ma}$ eustatic lowering (51); backstripping yields a sea-level estimate of $56.5 \pm 11.5 \mathrm{~m}$ for this event (pink bar on Fig. 3). Our estimate for this event is $\sim 40 \pm 15 \mathrm{~m}$ (Fig. 1); these estimates are consistent, within error, but suggest that we may underestimate sea-level falls by 5 to $30 \mathrm{~m}$. 
The record of the past $130 \mathrm{ky}$ illustrates the errors in converting a $\delta^{18} \mathrm{O}$ record into a sealevel proxy (fig. S1). Benthic foraminiferal $\delta^{18} \mathrm{O}$ records can be scaled to a faithful proxy for glacial to cool interglacials [Marine Isotope Chron (MIC) 2d to 5d] (fig. S2), with sea level and $\delta^{18} \mathrm{O}$ in phase and lagging insolation. However, large deviations of the $\delta^{18} \mathrm{O}$-based sea-level curve occur during peak warm intervals (Holocene and MIC 5e) (Fig. 2), with a hint that deep-sea temperature change leads sea level. We have attempted to correct for this temperature effect by scaling to the Barbados sea-level record (6). However, this results in underestimating amplitudes of glacials and overestimating amplitudes of interglacials, with a resultant $20 \%$ uncertainty.

\section{Relation of Sea Level to Evolution and Climate Changes}

Episodes of supercontinent rifting and sea-level rise on the $10^{7}$ - to $10^{8}$-year scale played a role in phytoplankton evolution since the Proterozoic by flooding continental shelves and low-lying inland areas and increasing the total length of coastline. The resulting increases in habitat heterogeneity, ecospace, and nutrient availability favored plankton that lived along continental margins. Accordingly, diversity increases in phytoplankton (Fig. 2) appear to correlate with continental rifting of Pannotia (Early Paleozoic) and Pangea (Jurassic) (Fig. 2), ultimately resulting in the three groups of eukaryotic phytoplankton (coccolithophores, diatoms, and dinoflagellates) that dominate the modern ocean (52).

Sea-level changes are expected with beats of 19/23, 41, and $100 \mathrm{ky}$, but similar changes on the $10^{6}$-year scale (Fig. 3) have puzzled geologists. Sea-level cyclicity on the $10^{6}$ year scale can be explained by a modulation of the shorter term Milankovitch-scale sea-level events (fig. S5). For example, a prominent seismic disconformity spanning the Oligocene/Miocene boundary $(\sim 23.8 \mathrm{Ma})$ on the New Jersey slope (13) can be correlated to a detailed $\delta^{18} \mathrm{O}$ record at deep-sea Site 929 (53), showing that the $10^{6}$. year scale sea-level fall at the Oligocene/ Miocene boundary occurred as a series of $41-\mathrm{ky} \delta^{18} \mathrm{O}$ increases and sea-level changes. The 41-ky sea-level falls are reflected in core photographs by a series of dark-light changes (fig. S5), resulting from variations in glauconite transported downslope during lowstands. The seismic reflection is a concatenation of these beds and the ice-volume events that caused them.

The high sea levels of the Late Cretaceous and early Eocene are associated with peak benthic foraminiferal $\delta^{18} \mathrm{O}$ values (Fig. 3) (table $\mathrm{S} 1$ ), and it has long been suggested that sea level covaries with $\delta^{18} \mathrm{O}$ on the $10^{7}$-year scale [e.g., (54)]. On the $10^{5}$ - to $10^{6}$-year scales, such covariance can be explained by ice-volume changes in concert with temperature changes $(8,13)$. However, this cannot be true on the $10^{7}$ - to $10^{8}$-year scale because most of the

variations controlled by tectonics (changes in ocean-crust production and mountain uplift).

High ocean-crust production rates have long been linked to high sea level, high $\mathrm{CO}_{2}$, and warm global temperatures [e.g., (54)]. Warm Late Cretaceous climates and elevated sea level may be attributable to moderately higher sea-floor production rates, although our results require that crustal production rates were lower than previously thought. However, the intensity of spreading ridge hydrothermal activity (a major source of $\mathrm{CO}_{2}$ outgassing) appears also to correlate with times of major tectonic reorganizations (56). We propose that the early Eocene peak in global warmth and sea level (Fig. 3) was due not only to slightly higher ocean-crust production but also to a late Paleocene-early Eocene tectonic reorganization. The largest change in ridge length of the past 100 My occurred $\sim 60$ to $50 \mathrm{Ma}$ (57), associated with the opening of the Norwegian-Greenland Sea, a significant global reorganization of spreading ridges, and extrusion of 1 to $2 \times 10^{6}$ $\mathrm{km}^{3}$ of basalts of the BritoArctic province (58). A late Paleocene to early Eocene sealevel rise coincides with this ridge-length increase, suggesting a causal relation. We suggest that this reorganization also increased $\mathrm{CO}_{2}$ outgassing and caused global warming to an early Eocene maximum. Subsequent reduced spreading rates and hydrothermal activity resulted in lower long-term sea level, reduced $\mathrm{CO}_{2}$ outgassing, and a cooling of deep-water by $\sim 8^{\circ} \mathrm{C}(44) . \mathrm{CO}_{2}$ may have been further lowered by an increase in continental weathering rates during the remainder of the Cenozoic (59), explaining an additional deep-water cooling of $7^{\circ} \mathrm{C}$ to $9^{\circ} \mathrm{C}(44)$.

Our studies of the past 100 My provide clues to the tempo of climate and ice-volume changes for other Icehouse and Green-

$\delta^{18} \mathrm{O}$ signal must be attributed to temperature changes. For example, 3.6\% of the $4.4 \%$ o increase from 50 to $0 \mathrm{Ma}$ (Fig. 3) must be attributed to deep-water cooling $\left(15^{\circ} \mathrm{C}\right.$ overall $)$ rather than to ice storage (55). The link between sea level and temperature on the $10^{7}$ - to $10^{8}$-year scale cannot be due to cooling alone, because this would explain only $\sim 15 \mathrm{~m}$ of eustatic fall since $50 \mathrm{Ma}$. The link between $\delta^{18} \mathrm{O}$ and sea-level variations on the $10^{7}$ - to $10^{8}$-year scale can be explained by $\mathrm{CO}_{2}$ house worlds of the Phanerozoic (Fig. 2). Icehouse worlds of the past $33 \mathrm{My}$, the Pennsylvanian to Early Permian, Late Devonian, and Late Ordovician (60), can be characterized by ice-volume changes that caused sea-level variations up to $200 \mathrm{~m}$. Greenhouse worlds characterize much of the Phanerozoic, but we note that small $\left(10\right.$ to $\left.15 \times 10^{6} \mathrm{~km}^{3}\right)$, ephemeral ice sheets occurred in the Greenhouse of the Late Cretaceous to Eocene. This raises the question as to whether any portion of the 


\section{R E V I E W}

Phanerozoic was ice-free. The Triassic and Cambrian pose two of the best candidates for an ice-free world $(60)$, yet Haq $(11,16)$ noted numerous $10^{6}$-year scale sea-level variations at these times (Fig. 2). If corroborated, these changes suggest the presence of ephemeral ice sheets even in the warmest of the Greenhouse periods.

\section{References and Notes}

1. D. T. Donovan, E. J. W. Jones, J. Geol. Soc. (London) 136, 187 (1979).

2. W. C. Pitman III, X. Golovchenko, Soc. Econ. Paleontol. Mineral. Spec. Publ. 33, 41 (1983).

3. R. Revelle, Ed., Sea-Level Change (National Academy Press, Washington, DC, 1990).

4. D. Sahagian, M. Jones, Geol. Soc. Am. Bull. 105, 1109 (1993).

5. A. Cazenave, R. S. Nerem, Rev. Geophys. 42, RG3001 (2004).

6. R. G. Fairbanks, Nature 339, 532 (1989).

7. J. Chappell et al., Earth Planet. Sci. Lett. 141, 227 (1996).

8. K. G. Miller, J. D. Wright, R. G. Fairbanks, J. Geophys. Res. 96, 6829 (1991).

9. J. Zachos, M. Pagani, L. Sloan, E. Thomas, K. Billups, Science 292, 686 (2001).

10. P. R. Vail et al., Am. Assoc. Petrol. Geol. Mem. 26, 49 (1977).

11. B. U. Haq, J. Hardenbol, P. R. Vail, Science 235, 1156 (1987).

12. N. Christie-Blick, G. S. Mountain, K. G. Miller, in SeaLevel Change, R. Revelle, Ed. (National Academy Press, Washington, DC, 1990), pp. 116-140.

13. K. G. Miller et al., Rev. Geophys 36, 569 (1998).

14. A. B. Watts, M. Steckler, Ewing Series 3, 218 (1979).

15. L. L. Sloss, Geol. Soc. Am. Bull. 74, 93 (1963).

16. B. U. Haq, A. M. Al-Qahtani, GeoArabia 10, 127 (2005).

17. A. B. Ronov, Am. J. Sci. 294, 802 (1994).

18. G. C. Bond, Tectonophys 61, 285 (1979)

19. C. G. A. Harrison, in Sea-Level Change, R. Revelle, Ed. (National Academy Press, Washington, DC, 1990), Pp. 141-158.

20. J. D. Hays, W. C. Pitman, Nature 246, 18 (1973).

21. W. A. Van Sickel, M. A. Kominz, K. G. Miller, J. V. Browning, Basin Res. 16, 451 (2004).

22. M. A. Kominz, S. F. Pekar, Geol. Soc. Am. Bull. 113, 291 (2001).

23. The long-term record was computed as follows: (i) The median was interpolated at a $0.2 \mathrm{My}$ interval. (ii) A singular spectrum transform following the description of the VG algorithm in (61) was applied using a window length of 65 points ( $13 \mathrm{My}$ window). (iii) The curve was reconstructed from the first empirical orthogonal function resulting from singular spectrum analysis, which accounts for $58 \%$ of total variance in the interpolated series.

24. M. A. Kominz, Am. Assoc. Petrol. Geol. Mem. 36, 108 (1984).

25. D. B. Rowley, Geol. Soc. Am. Bull. 114, 927 (2002).

26. The development of an ice sheet the size of modern ice sheets would cause an $80-\mathrm{m}$ fall (62), but this would only explain a $\sim 54-\mathrm{m}$ eustatic fall after accounting for isostatic adjustment.

27. R. A. Berner, Z. Kothavala, Am. J. Sci. 301, 182 (2001).
28. G. C. Bond, M. A. Kominz, M. S. Steckler, J. P. Grotzinger, Soc. Econ. Paleontol. Min. Spec. Publ. 44, 39 (1989).

29. M. A. Kominz, Basin Res. 7, 221 (1995).

30. M. Levy, N. Christie-Blick, Geol. Soc. Am. Bull. 103 1590 (1991).

31. D. L. Anderson, Nature 297, 391 (1982)

32. A. D. Miall, J. Sed. Petrology 61, 497 (1991)

33. K. G. Miller et al., Geol. Soc. Am. Bull. 116, 368 (2004).

34. Water-depth changes were inferred from lithofacies and benthic foraminiferal biofacies studies of (63-66).

35. D. Sahagian, O. Pinous, A. Olferiev, V. Zakaharov, A. Beisel, Am. Assoc. Petrol. Geol. Bull. 80, 1433 (1996).

36. K. G. Miller, J. D. Wright, J. V. Browning, Mar. Geol. 218, 215 (2005).

37. A. Hallam, Phanerozoic Sea Level Changes (Columbia Univ. Press, New York, 1992).

38. J. Laskar et al., Astron. Astrophys. 428, 261 (2004).

39. R. V. Dingle, J. M. McArthur, P. Vroon, J. Geol. Soc. (London) 154, 257 (1997).

40. N. J. Shackleton, J. P. Kennett, Init. Repts. Deep Sea Drilling Project 29, 743 (1975).

41. J. D. Wright, in Tectonic Boundary Conditions for Climate Reconstructions, T. J. Crowley, K. Burke, Eds. (Oxford Univ. Press, New York, 1998), pp. 192-211.

42. J. D. Hays, J. Imbrie, N. J. Shackleton, Science 194, 1121 (1976).

43. M. E. Raymo, B. Grant, M. Horowitz, G. H. Rau, Mar. Micropaleontol. 27, 313 (1996)

44. K. G. Miller, R. G. Fairbanks, G. S. Mountain, Paleoceanography 2, 1 (1987)

45. Benthic foraminiferal $\delta^{18} \mathrm{O}$ records from 846 [0 to 6.136 $\mathrm{Ma}$, equatorial Pacific (67)] and 982 [6.139 to $9 \mathrm{Ma}$, northern North Atlantic (68)] were spliced to create a high-resolution $\delta^{18} \mathrm{O}$ composite record with a sample resolution of $3 \mathrm{ky}$ for the late Miocene to the present. Although they are located in different deep-water masses, the records yield similar values across the splice. The pre-late Pliocene $\delta^{18} \mathrm{O}$ record has average values $(2.9 \%$ ) that are $0.5 \%$ lower than modern values $(3.4 \%)$. Ice volumes during the late Miocene to early Pliocene were similar to the modern (69), indicating that this long-term $\delta^{18} \mathrm{O}$ offset reflects deep-water temperatures that were warmer relative to the modern. Thus, we incrementally added $0.5 \%$ to the values older than $3.5 \mathrm{Ma}$ as a linear function from 2.5 to $3.5 \mathrm{Ma}$. We converted the adjusted $\delta^{18} \mathrm{O}$ composite record to a sea-level estimate (Fig. 2) by scaling to a calibration of $0.1 \% / 10 \mathrm{~m}$. Our initial sea-level and $\delta^{18} \mathrm{O}$ estimates showed a change from the last glacial maximum to modern changes of $1.5 \%$; this change has been calibrated in Barbados as $1.2 \%$. The difference is due to glacial-interglacial deep-sea temperature changes of $\sim 2^{\circ} \mathrm{C}(6)$, as illustrated on Fig. 3 . We scaled the sealevel curve by 0.8 to account for this difference (Fig. 4).

46. K. W. Ramsey, Delaware Geol. Surv. Rept. of Investigations 54, 1 (1996).

47. J. P. Donnelly, P. Cleary, P. Newby, R. Ettinger, Geophys. Res. Lett. 31, L05203 (2004).

48. W. R. Peltier, Rev. Geophys. 36, 603 (1997).

49. R. G. Lighty, I. G. Macintyre, R. Stuckenrath, Coral Reefs 1, 125 (1982).

50. Paleowater depth estimates are a critical data set needed for backstripping. Paleowater depth estimates of shallowshelf (neritic) environments are relatively precise $( \pm 15 \mathrm{~m})$, but uncertainties increase into middle-shelf $( \pm 30 \mathrm{~m})$ outer-shelf $( \pm 50 \mathrm{~m})$, and slope $( \pm 200 \mathrm{~m})$ environments. The errors in paleowater depth estimates correspond to eustatic errors correcting for loading of $\pm 10,20,35$, and $120 \mathrm{~m}$, respectively. Most of our sections are inner to middle neritic, with eustatic errors of \pm 10 to $20 \mathrm{~m}$.

51. C. M. John, G. D. Karner, M. Mutti, Geology 32, 829 (2004).

52. M. E. Katz, Z. V. Finkel, D. Grzebyk, A. H. Knoll, P. G Falkowski, Annu. Rev. Ecol. Evol. Syst. 35, 523 (2004)

53. J. C. Zachos, B. P. Flower, H. Paul, Nature 388, 567 (1997).

54. R. L. Larson, Geology 19, 547 (1991).

55. This assumes that a global equivalent of $0.9 \%$ is stored as ice today (70).

56. M. Lyle, M. Leinen, R. Owen, D. K. Rea, Geophys. Res. Lett. 14, 595 (1988).

57. S. C. Cande, D. V. Kent, J. Geophys. Res. 97, 13917 (1992).

58. D. G. Roberts, A. C. Morton, J. Backman, Init. Rept. Deep Sea Drilling Proj. 81, 913 (1984).

59. D. L. Royer, R. A. Berner, I. P. Montañez, N. J. Tabor D. J. Beerling, GSA Today 14, 4 (2004).

60. L. A. Frakes, E. Francis, J. I. Syktus, Climate Modes of the Phanerozoic (Cambridge Univ. Press, Cambridge, 1992).

61. M. R. Allen, L. A. Smith, J. Climate 9, 3373 (1996).

62. R. S. Williams, J. G. Ferrigno, U.S. Geol. Surv. Prof. Pap. 1386-A (1999).

63. K. G. Miller, S. W. Snyder, Proc. ODP, Scientific Results 150X, 1 (1997).

64. K. G. Miller et al., Proc. ODP Init. Rep. 174AX, 43 (1998).

65. K. G. Miller et. al., Proc. ODP Init. Rep. 174AXS, 1 (1999).

66. K. G. Miller et. al., Proc. ODP Init. Rep. 174AXS, 1 (2001).

67. N. J. Shackleton, M. A. Hall, D. Pate, Sci. Res. ODP 138, 337 (1995).

68. D. A. Hodell, J. H. Curtis, F. J. Sierro, M. E. Raymo, Paleoceanography 16, 164 (2001).

69. D. R. Marchant, G. H. Denton, C. C. Swisher, Geografiska Annaler 75A, 269 (1993).

70. N. J. Shackleton, J. P. Kennett, Initial Rep. Deep Sea Drill. Proj. 29, 743 (1975).

71. W. A. Berggren, D. V. Kent, C. C. Swisher, M.-P. Aubry, Soc. Econ. Paleontol. Mineral. Spec. Publ. 54, 129 (1995)

72. F. M. Gradstein et al., J. Geophys. Res. 99, 24051 (1994).

73. We thank W. Van Sickel and A. Stanley for contributions to development of the sea-level curves, D. Sahagian for reviews, P. Falkowski and D. Kent for comments, and the members of the Coastal Plain Drilling Project (ODP Legs 150X and 174AX) who are not listed here for contribution of critical data sets that led to the curve. Supported by NSF grants OCE 0084032, EAR97-08664, EAR99-09179, and EAR03-07112 (K.G.M.); EAR98-14025 and EAR037101 (M.A.K.); and the New Jersey Geological Survey. Samples were supplied by the Ocean Drilling Program.

Supporting Online Material

www.sciencemag.org/cgi/content/full/310/5752/1293/ DC1

Figs. S1 to S5

Table S1

10.1126/science. 1116412 